\title{
PLANNING FOR MANAGED FORESTS ${ }^{1}$
}

\author{
By H. P. EISLER
}

Department of Natural Resources and Industrial Development, Saskatchewan

$\mathrm{T}$

HIS IS AN introductory paper to pave the way for the programme in hand. It is not the purpose of this paper to give you many, if any, pertinent points for discussion with regard to the planning for managed forests. You will have during the remainder of to-day the pleasure of hear. ing individual papers dealing with specific divisions of this very important subject. Within these papers will be presented definite suggestions as to the immediate necessity for and possibilites of planning for managed forests.

Most of us can recall early school days when our studies in forestry led us to the then existing text books an forest management and their almost complete reference to European forests. We read and studied with great interest of the forests of France, Germany and the Scandinavian countries which had been under sustained yield management for years and centuries. We learned to think in terms of clear-cutting, selection cutting, shelterwood and seed tree methods and to appreciate the relationship between forest capital and annual growth and a cutting budget based on a combination of these factors. We may even have looked forward with anticipation to graduation and to the day when we would go out into the world and practise forestry.

Imagine then our consternation and bewilderment when actually rubbing shoulders with the forests of our particular locality we discovered that forest management in Canada was an almost unknown quantity. Our early efforts at this stage largely consisted of timber cruising, requiring principally an estimate of the amount of timber to be offered for sale supported by a map showing the forest types and a written report that variously covered soil; topography, silvicultural conditions and whatever additional information the cruiser felt inclined to add of his own free will. In the course of time log. ging operations were commenced and we probably spent a good deal of our time inspecting the cutting to see that the operations conformed to the terms of contract with regard to trees cut, stump height, top utilization and brush disposal. And so finally the area was cut out and we wrote a closing out report descriptive of the operation and the character of the residual stand. The file was closed and probably stored away in some remote corner to be forever forgotten.

\section{Forest Protection}

Coincident with this early apprenticeship came a realization that the forest fire menace was a very important part of forestry and an ever present menace to the forest. Every spring we hoped that weather conditions would be so favourable that there would be no disastrous fires. For after many years of experience in fire suppressian we realize that the weather man remains the one and only dependable saving factor from the forest fire menace.

1 Paper pregented at the annual meting of the Canadian Society of Forest Engineers, January 30-31, 1946, Regina, Saskatchewan. 
And so to-day forest management means to most of us a combination of : harvesting the timber of our locality and an attempted protection of that timber from total destruction by forest fires.

There can be no attempted management of the forests until the forest fire menace has been decisively curtailed. When the heavy losses from insect depredations and the less spectacular but none the less tremendous losses from fungus diseases are considered it will readily be appreciated that protection is a major problem. However, the subject under discussion today is forest management and we will find it difficult to give this major subject of protection proper consideration and attention.

\section{Forest InVENTORY}

It may be said that there are today no managed forests in Canada comparable to the so-called sustained yield forests of European countries. However, we do have some form of attempted direction toward management. Thus every province in the Dominion has its forest service with its own form of forest regulations setting out what timber may be cut and under what conditions the cutting may be done. There have been, in addition, a series of sporadic attempts at fact finding, aiming at a basis for forest management.

Thus the Dominion Forest Service in the early part of 1925 issued fairly detailed instructions covering four types of surveys-reconnaissance, stock taking, timber sale and working plan. I believe that, in the three Prairie Provinces at least, one area in each province was specially selected for a working plan survey resulting in the collection and compilation of very detailed information with the object of putting that area under management. At a somewhat later date stock taking surveys were commenced but the work progressed slowly and the total area covered was comparatively small. During 1931 and 1932 a determined effort was made to cover appreciable areas of the Province of Saskatchewan. Unfortunately, the funds available were rather restricted and, in order to make a showing, portions of the Parkland or semi-prairie belt of this province were selected wherein it was possible to carry on a so called "car reconnaissance". That is to say, two men working together travelled the north and south and east and west roads by car and estimated the amount of area in terms of poplar bluffs, prairie land and cultivated land. While the information obtained was important in itself, it did not give us any information about timber conditions within the real timber belt where almost all the commercial logging operations have been centred.

The most outstanding advancement in the field of forest inventory occurred around 1929 when the Dominion Forest Service commenced the interpretation of aerial photographs and the production of aerial forest cover type maps. As you know, these have topographical features as a base to which is added the forest cover by local types showing species and general estimates. Unfortunately the Dominion Forest Service was still further curtailed during 1933 and the carrying on of the forest inventory was en- 
tirely discontinued during that year. The Saskatchewan Department of Natural Resources has obtained the co-operation of the Dominion Forest Service in the preparation of aerial forest cover type maps of special areas from time to time since that date.

Very little effort has ever been made to make use of the working plan, stock taking or car reconnaissance data as the basis for a management plan in the sense of formulating plans for the future on the foundation of the knowledge of present timber supplies or lack of supplies on any specific area. The data obtained and particularly the maps were very useful in directing the locale of the subsequent woods operations. There was only one instance in Saskatchewan where aerial photographic maps. plus all other available data, were used in an attempt to produce a working plan. The area in this instance centred on a certain river used as a means of transporting logs many miles to an established sawmill. The outstanding result of this investigation was to show that, had the area been placed under management some years previously the company could have operated profitably according to a sustained yield plan.

Actually what has happened in Saskatchewan is that we have become progressively stricter with regard to diameter limits and utilization requirements. But we have not taken advantage of the data given to us and set up for any particular area, a sort of card index record of timber resources available to be balanced against depletion in the form of utilization, fire losses and destruction by insects or fungi. In other words, we do not know what our balance sheet should show.

The type of timber harvesting going on in Canada is generally dictated by the occurrence of the desirable species in sufficient merchantable quantity to make logging operations an economic possibility. We would like our areas to be logged over in such a manner that there would be a continuation of or improvement over the original forest. Here in Saskatchewan we are attempting to obtain this condition by either leaving sufficient small diameter trees to form the basis of a second cut in the near future or to provide for the restocking of the cut-overs to the desired species. Unfortunately, we do not know how to arrive at either one of these two desirable goals.

The Dominion Forest Service originally about 1930, planned to set up a series of experimental stations across Canada for the purpose of investigating various cutting methods within the individual forest regions. The intention was to determine the conditions best suited to the continuation and improvement of the original forest, but there were insufficient funds and personnel to complete this programme.

We really have been lulled into a sort of irresponsibility by our public school text-books which portrayed a Canada of unlimited timber resources, rivers teeming with fish, and so on. But of recent years we have become increasingly aware that our timber resources are not inexhaustible. Here in Saskatchewan - and I expect it applies to many other areas in Canada-the sense of the inevitable has been further high-lighted by the almost 
overnight transition from horse logging to power logging. Camps which formerly required 250 men to log five million feet have now been reduced to a crew of fifty men. Where the logs were ordinarily decked in the woods and later hauled to the mill, the mill has now moved to the woods and so-called hot logging is the accepted practice. Even with this recent innovation in logging practices, we can see the end of our virgin timber supplies in Saskatchewan. Timber tracts that were considered to be inaccessible ten or fifteen years ago have now been brought into the accessible class through the use of tractors, trains and trucks. Formerly inaccessible areas will continue to come into production as long as there is a heavy demand for timber products and high market prices. But there will come a day in the not too distant future when we will find that we are sliding back toward normal or even subnormal conditions. Operation profits may become so small that it will be no longer possible to go further afield for timber stands and we will find ourselves with only cut-over areas as a source of timber supplies.

I must apologize at this point for having referred to Saskatchewan almost entirely. It so happens that I have spent most of my working years in this province and so it is only natural that I should use it as an example.

The time has definitely arrived when we must strike a balance between timber resources and depletion. There can be no planning for managed forests until there be a complete forest inventory. There is as little chance of managing a forest without a thorough knowledge of the timber resources as there is in carrying on a grocery business without knowing what goods are on the shelves. It has been stated previously that, in Saskatchewan at least, this work came to a standstill in the early part of 1933. Actually there had been a rather large part of the northern part of Saskatchewan photographed under the direction of the topographical surveys branch. The result has been the mapping of an extremely large area of the most northerly portion of Saskatchewan and the transition of a hitherto blank area on the map to a most amazing lacework of lakes and streams. As indicated the Dominion Forest Service entered the picture about 1929 and began the interpretation of the aerial photographs in terms of forest cover types. Most of the photographic work in Saskatchewan has been carried out in the inaccessible and unmerchantable timber areas of the northern coniferous belt. Photographic surveys have covered a comparatively small part of the commercial timber belt of the province. Of these, quite a fair proportion are obsolete because of the time that has elapsed since the photographs were taken with subsequent modification of the forest cover by forest fires, log. ging operations and insect infestations. Aerial photographic work is certain to form an outstanding contribution to the post-war programme. The production of aerial forest-cover type maps requires the co-operation of the Interdepartmental Committee on Air Surveys to take the photographs, the Bureau of Geology and Topography to plot the topographic details for the base map, and the Dominion Forest Service to interpret and plot the cover types. It seems likely that these last two services will have to be greatly 
expanded if they are to cope with the requests from all provinces. It may be that each province will have to develop its own forestry personnel for the interpretation of the forest data.

\section{Absorption of Returned Service Men}

There are bound to be large numbers of returned service men either seeking employment in forestry work or looking for a chance to go farming. In Saskatchewan we already have quite a number of these men seeking employment in forestry work. There is in existence a working arrangement between the Dominion and Provincial governments making provision for the taking on of a limited number of these men as trainee assistants to regular field officers. There is also a vocational course in forestry being sponsored by the Canadian Legion. And finally, tentative arrangements have been made with the University of Saskatchewan to provide elementary instruction in arithmetic, botany, geology, soils and forestry subjects. Actually none of these possibilities has progressed to the stage of definite assurances of employment. We have engaged only a small number of trainees; and the present situation is rather disheartening to say the least and something should be done and done at once to place these men in some form of forestry employment.

It is true that every war of recent times has been followed by a land settlement scheme. Large numbers of men will be looking toward the three Prairie Provinces for prospective farming opportunities; but too many glamorous pictures have been painted about the golden possibilities of western farm lands. The actual facts are that the fertile prairie areas have long since been taken up by individuals, corporations and companies. There have been some wonderful successes. There have also been failures. Settlement has progressed beyond the prairies, through the so-called parkland belt, and is already knocking at the door of the timber belt.

The prairies are not all fertile agricultural land. The prairies include sub-marginal lands as well as definitely bad lands from a farming standpoint. And then there is the parkland belt with its characteristic bluffs of poplar interspersed with prairie land. The parkland belt is well settled by farmers who, in their quest for a fortune in golden wheat, are continuing to clear off as much of the poplar as possible to put the greatest acreage under wheat. I know of such areas formerly fairly well covered by light poplar that have been cleared of their natural timber cover and are now subject to as much soil drifting as is common to the poorer or over-worked areas of the prairies.

\section{Soll Surveys and Land Classification}

Finally there is the timber belt, the southern edge of which is even today spotted with squatters and homesteaders. Some of the areas have been covered by soil surveys and sufficient information obtained to classify them as grey wooded soils. They are much lower in fertility than the prairie soils and the fertility that does exist should be carefully guarded and maintained or added to by rotation crops and mixed farming. I know 
from my own experience in land examination that too many of these homesteaders consider the value of the land in direct proportion to the absence of trees on that land. Fire has always been taken for granted as a universal means of clearing the land and it is a well established fact that the settler is one of the biggest if not the biggest contributor to forest fires from year to year. He may save himself many backbreaking hours of labour in clear ing by hand, but as against this he destroys much of the meagre fertility of the soil, he destroys the value of the timber on his land and he seriously menaces the adjacent forest "which for many of the early years of his struggle for subsistence is likely to furnish him with a large part of his cash income. Soil surveys should precede all settlement of timbered lands and should form the basis for a definite determination of agricultural and non-agricultural lands. These costly maps and detailed studies are supposed to provide not only a guide to the settler but a barrier to the encroachment on absolute forest land. Settlement should only be permitted on forested land when the area of arable land is sufficiently large for the establishment and maintenance of a self-contained community including schools, churches and other social requirements. A misplaced settlement on non-agricultural soil represents a bad "loan". It cancels not only the state-owned resources of forest and soil, but it cancels even more tragically the human values which are supposed to be preserved by the investment.

\section{Inter-PROVINCLAL AND DOMINION INTERESTS}

We commonly think of the forest in terms of timber and a variety of timber products, from which there has been for years a steady flow of revenue to the individual, the Province and the Dominion. To this extent Provincial boundaries lose their significance so that the forest resources of any one part of the Dominion are of interest to every other part of the Dominion. Fortunately, a very large part of the forested area of the Dominion is under state control but on the other hand this very fact places the responsibility of management on the shoulders of the various governmental departments.

We mostly think of the forest in terms of forest products and revenue but the forests also exert a most important influence on fish, wild life, watershed and water-table control. An example of the inter-provincial interest is the need for the maintenance of protection forests on the east slope of the Rocky Mountains as a controlling influence on the streams and rivers rising in the mountains and flowing eastward through the three Prairie Provinces.

While it is true that the state owns and controls almost all of the forests there have been instances of the partial relinquishment of complete governmental control-as, for example, in allowing certain heavily financed pulpwood companies to acquire extensive tracts of timber to protect their investment subject to the approval of the company cutting plan by the Provincial Government concerned. 


\section{Conclusion}

This paper has attempted to show that planning for managed forests will require at least the following fundamentals:

1. The forest fire menace must be drastically curtailed, insect infestations eliminated and losses from fungus diseases reduced.

2. An immediate inventory of the forest resources and their accessibility in any given region.

3. Immediate plans for the rehabilitation and absorption of returned service men in forestry work.

4. Soil surveys defining agricultural and non-agricultural lands and the directed establishment of self-contained settlements.

5. An appreciation of the inter provincial and overall Dominion interest in our forests and the need for co-operation in the management of these forests.

There never was a time when the striking of a balance between timber resources and depletion was so urgent. There never was a time comparable to the present post-war period as regards the opportunity to further the interests of forestry. You have the necessity and you have the opporunity. It is now your responsibility to carry out your part in planning for managed forests.

A century or centuries are required to produce a forest equivalent to our present day natural forests that have been literally handed to us as a gift. There must, therefore, be a Dominion-wide accepted attitude toward the forests, that can be carried forward regardless of temporary setbacks. Unfortunately, forestry has been subject to the ideas of the particular governmental party then in power. No forestry planning for managed forests can be accomplished until that plan is free from political change of ideas, an example-the forests of France and Germany have been sacrificed and butchered for the needs of World Wars Nos. I and II. But we definitely expect that the chaos will be brought into order and these forests restored to their normal expectancy. How can we here in Canada think in the same terms of planned forestry when we see the following: in 1930 and prior to the transfer of the resources to the Province we had one nursery about to produce an output of one million trees annually; shortly thereafter, this nursery was abandoned and today you can still see the transplants and seedlings run riot in their original setting. In 1942 we were asked to produce sufficient trees to plant 1000 acres a year. Plans went forward, but today we are again faced with the possibility of nursery abandonment because it is too costly an undertaking. Whether we like it or not, there are thousand of acres of forest land in Saskatchewan that can only be brought back into productivity through planting. Unproductive acres are waste acres and must be brought into production through long' time planning as a part of the management of forests and forest land. 